\title{
電子顕微鏡による $\mathrm{Al}-1.6$ at $\% \mathrm{Cu}$ 合金における \\ $\theta^{\prime} \rightarrow \theta$ 相変態の研究
}

\author{
呂 忱* 藤田廣志 ${ }^{* *}$ 田口英次 ${ }^{* * *}$
}

J. Japan Inst. Metals, Vol. 55, No. 2 (1991), pp. 110-117

An Electron Microscope Study of $\theta^{\prime} \rightarrow \theta$ Phase Transformation in Al-1.6 at\% $\mathrm{Cu}$ Alloys

Chen Lu*, Hiroshi Fujita** and Eiji Taguchi***

Details of the $\theta^{\prime} \rightarrow \theta$ phase transformation in an Al-1.6 at $\% \mathrm{Cu}$ alloy have been investigated by high resolution electron microscopy including in-situ experiments. The results obtained are summarized as follows.

(1) Growth of $\theta^{\prime}$-phase occurs by movement of both the incoherent interfaces and ledges of the stepped structure on $\theta$-phase coherent interfaces, and a large coherent strain is induced at the growth front so that the interfacial dislocations are formed.

(2) $\theta$-phase crystals are frequently formed at the intersection between two $\theta^{\prime}$-phase structures.

(3) $\theta$-phase crystals of rod-shape grow to platelets with a large aspect ratio by absorbing the $\theta^{\prime}$-phase nearby, but the interfaces of both structures are separated from each other in general.

(4) The interface of $\theta$-phase crystals has also a stepped structure whose main component is one of the $\{110\}_{\theta}$ planes of the $\theta$-phase, and its average orientation is inclined at about $13^{\circ}$ against one of the $\{100\}_{\alpha}$ planes of the matrix aluminum in this alloy. The average orientation widely changes in the foil specimens by in-situ aging in general.

These results are discussed from a viewpoint of the interfacial energy based on the orientation relationships among the matrix, $\theta^{\prime}$-and $\theta$-phase structures.

(Received June 13, 1990) Keywords: $\theta^{\prime}$-phase, $\theta$-phase, phase transformation, interface, stepped structure, aluminum-copper
alloy

I. 緒言

時効性合金の析出過程は, G. P. ゾーン(一種のアトム． クラスター) $\rightarrow$ 中間相 $\rightarrow$ 平衡相の過程をとることが多い.

$\mathrm{Al}-\mathrm{Cu}$ 低濃度合金 $(<2.5 \mathrm{at} \% \mathrm{Cu})$ はその代表的なものであ る.この合金の析出過程は古くより注目され，その初期に はX 線法を中心に ${ }^{(1)}$, 最近では, 透過電子顕微鏡法 ${ }^{(2)-(3)}$ (以下電顕) とか，FIM 法を用いた原子構造の直接観 察 ${ }^{(4)-(6)}$, オージェ電子分光法による荷電子の挙動の研 究(7)など, 幅広い研究がなされている. それにもかかわら ず，各段階における相変態機構とその成長過程の詳細につ いては以下のように不明な点が多い。(1)初期時効条件と G. P. ゾーンに打ける $\mathrm{Cu}$ 原子の凝集状態との関係，(2)凝 集した $\mathrm{Cu}$ 原子集団の時効による変化, 特に中間相 $\theta^{\prime} へ の$ 転移過程, および(3) $\boldsymbol{\theta}^{\prime}$ 相から平衡相 $\boldsymbol{\theta}$ 相への相变態機構.
これらの問題の中で, 本研究では主として $\theta^{\prime} \rightarrow \theta$ 相変態 について調べた. この問題については, すでに透過電顕法 によるその場観察が行われている(8)が, 当時は低電圧であ ったために現象が試料厚さの効果を強く受けている可能性 があり，また分解能も十分とはいえなかった．本研究で は, 超高電圧および高分解能電顕によるその場観察を中心 として, 結果の信頼度を高めると共に, 原子尺度の観察を 行った.

\section{II. 試料および実験方法}

試料には Al-1.6 at\% Cu の $\{100\}$ 面方位の単結晶を用い, 放電加工機による直径 $3 \mathrm{~mm}$, 厚さ $130 \mu \mathrm{m}$ の円盤を切り 出した.これを $800 \mathrm{~K} て ゙ 36 \mathrm{ks}$ の溶体化処理をした後, 氷水中に焼き入れ, 種々の温度と時間で時効処理を行っ た。その後, $\mathrm{HClO}_{4}(20 \mathrm{vol} \%)+\mathrm{CH}_{3} \mathrm{COOH}(80 \mathrm{vol} \%)$ の

\footnotetext{
* 大阪大学大学院生 (Graduate Student, Osaka University, Suita)

** 大阪大学工学部材料物性工学科, 現在 : 近畿大学理工学総合研究所(Department of Materials Science and Engineering, Faculty of Engineering, Osaka University, Suita. Present address: Research Institute for Science and Technology, Kinki University, Higashi-Osaka)

*** 大阪大学工学部材料物性工学科 (Department of Materials Science and Engineering, Faculty of Engineering, Osaka University, Suita)
} 
混合液でジェット研磨を行い， $\mathrm{C}_{2} \mathrm{H}_{5} \mathrm{OH}(80$ vol\%)+ $\mathrm{HClO}_{4}(20 \mathrm{vol} \%)$ の混合液を用いて, 電压 $30 \mathrm{~V}$, 液温 $208 \mathrm{~K}$ で仕上げ研磨を行い，電影用試料とした．以後特に 薄膜時効とことわらない限り，試料はこの上うにバルクの 状態で時効したるのである， $\theta$ 相の核形成段階の試料につ いては，日立 $\mathrm{H}-800$ 型 $200 \mathrm{kV}$ 電顥内での加熱実験を行 い, $\theta^{\prime} \rightarrow \theta$ 相変態とその後の成長過程をその場観察した。 さらK，H-9000 型 $300 \mathrm{kV}$ 高分解能電顕を用いて， $\theta$ 相 と母相との界面を高分解能で観察した。 その際, 高分解能 用の結像条件には軸上照射を用いた。

\section{III. 実 験 結 果}

\section{1. 電顕内その場加熱実験による $\theta^{\prime} \rightarrow \theta$ 相変態の動的観 察}

Fig. 1 は $443 \mathrm{~K}$ で $86.4 \mathrm{ks}$ 時效した試料で得られた典 型的な中間相 $\theta^{\prime} の\{100\}_{\theta^{\prime}}$ 面格子像の一例で，舟相の $\{200\}_{\alpha}$ 面間隔を基隻として央测したc軸の長さは従来測 定されている 0.58 。 $\mathrm{nm}$ である，写真中Cで示した右端界 面では，c軸方向の格子常数の差によって，矢印で示すよ らに導入された界面転位の配列が観察される。それと同時 に上下の $\mathrm{A}$ 和よび $\mathrm{B}$ の整合界面でも，特に $\mathrm{A}$ の部分に見 られるよらに界面はそれほど明瞭でなく，頻度よく buffer layer ${ }^{(9)}$ が観察される。李たCの部分の不整合界面て は，その近傍，特に母相側に暗いコントラストが現れ，界

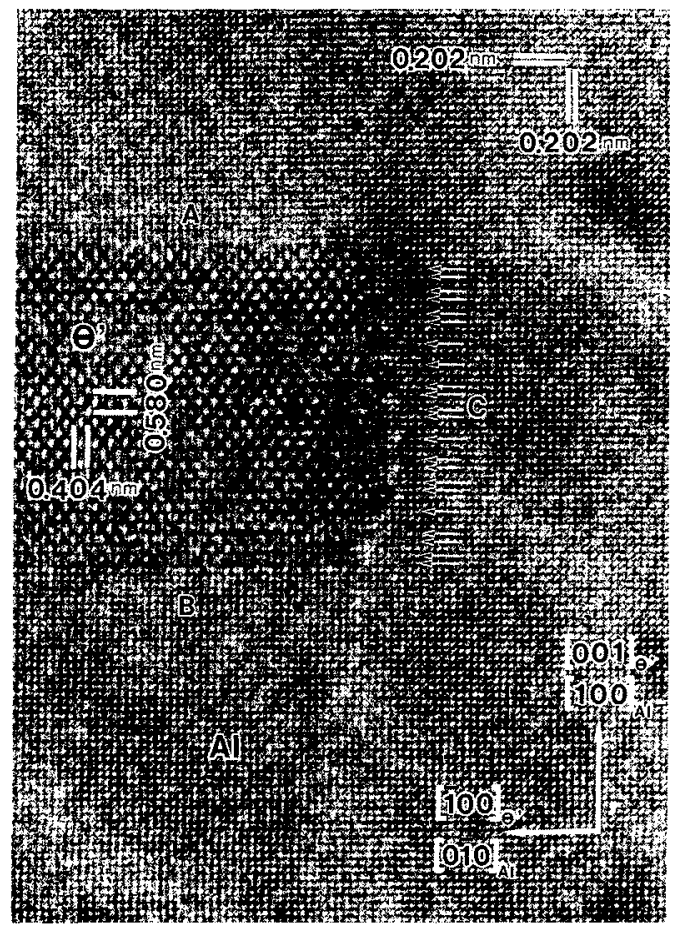

Fig. 1 Lattices imags of $\theta^{\prime}$-phase interface. The bulk specimen was aged at $443 \mathrm{~K}$ for $86.4 \mathrm{ks}$.
面転位を介して $\theta^{\prime}$ 相と母相の結晶面がう菓くがるよう に互いに変位している。このことから，界面エネルギーの 大きいことが分かるが，この上らに $\theta^{\prime}$ 相の成長先端で格 子欠陷执よび格子歪の多いことは $\theta^{\prime}$ 相の成長機構および $\theta^{\prime}$ 相から $\theta$ 相への相変態を調べる上で重要である゙。なお, $\theta^{\prime}$ 相と母相との結晶方位関係は Fig. 1 から分かるように

$$
[100]_{\alpha} / /[001]_{\theta^{\prime}} \quad[010]_{\alpha} / /[100]_{\theta^{\prime}}
$$

である(10)

Fig. 2 および 3 は，薄膜試料での $\theta^{\prime}$ 相から $\theta$ 相への相 変態過程のその場加熱実験による連続観察の例を示す. Fig. 2 は 2 枚の $\boldsymbol{\theta}^{\prime}$ 相が合体した部分に安定相 $\theta$ の核が形 成する連続観察の一例で，試料には $523 \mathrm{~K}$ で $10.8 \mathrm{ks}$ 時効 したものを用い，これに薄膜時効を施した．写真(a)は合 体する直前の 2 枚の $\theta^{\prime}$ 相の様子を，(b)は右側の $\theta^{\prime}$ 相がさ らに成長して互いに垂直にぶつかっているところの様子を 示す. 写真(b)では网者の相遇点のところの母相に暗いコ ントラストが強く現れている。このことから，合体時には その部分で局所的に結晶が激しく歪さことが分かる. 次の 写真 (c)では, この合体部の右側の $\theta^{\prime}$ 相の先端に $\theta$ 相が形 成され，その成長と同時に(b)で左下隅に観察されていた $\theta^{\prime}$ 相が合体部で急速に $\theta$ 相に昅取されていくことが分か る。倍率を下げた写真 $(\mathrm{d}) 〜(\mathrm{f})$ では右側にあった $\theta^{\prime}$ 相も急 速に $\theta$ 相に吸收されている．Fig. 3 は $523 \mathrm{~K} て ゙ 10.8 \mathrm{ks}$ 時 効した試料を $673 \mathrm{~K}$ で更に薄膜時效した時の $\theta$ 相形成の 過程で，符号 1 で示した $\theta^{\prime}$ 相の左下部に $\theta$ 相が形成され， (a) (f) で次第に成長していくことが分かる. それと同時 に，符号 1 の $\theta^{\prime}$ 相自体もその $\theta$ 相に吸收されていること が符号 2 で示した $\theta^{\prime}$ 相の位置から判別することが出来る.

\section{2. バルク試料中の $\theta^{\prime} \rightarrow \theta$ 相変態に伴う組織変化}

Fig. 4 は，Fig. 1 と同様にパルク試料を $623 \mathrm{~K}$ で 0.3 $\mathrm{ks}$ 時効した舟のを，試料面を $\mathrm{Al}$ 母相の $\{100\}$ 面(以下 $\left.\{100\}_{\alpha}\right)$ 薄膜に仕上げて電影観察した例である。この写真 中，暗い複雑な型の輪として現れているものは試料面 $\{100\}_{\alpha}$ に平行に形成された $\theta^{\prime}$ 相であり，\{100 $\}_{\alpha}$ 面に垂直 なものは結晶面が $\mathrm{Al}$ 母相と同一のために $\theta^{\prime}$ 相の周辺に整

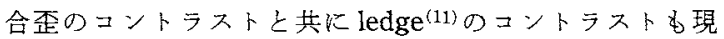
れている。これに対して， $\theta$ は舟相に対して対称性の悪い 構造であるために頻度よく暗いコントラストを生ずるとと むに，母相の $\{100\}_{\alpha}$ 面の1つに漂ぼ13度の傾をむつ棒

†C界面では，界面転位之固溶銅原子との相互作用に上 って銅原子が界面へ凝集する速度は $\mathrm{A}, \mathrm{B}$ 界面より早 く，そのために， $\theta^{\prime}$ 相の成長はC 界面で迅速に行われ る. その結果，C界面近傍での銅原子濃度は母相より さしろ低くなり，buffer layer は形成され難い。これ に対して，A，B界面は歪が少ないために全体としてそ の法線方向には成長し難く，C界面之同性質の階段状 構造の ledge の移動によってのみ成長は可能になる。 そのために，この界面には界面エネルギ一を隇少さ世 るための buffer layer は形成され易くなると考觉られ る。 

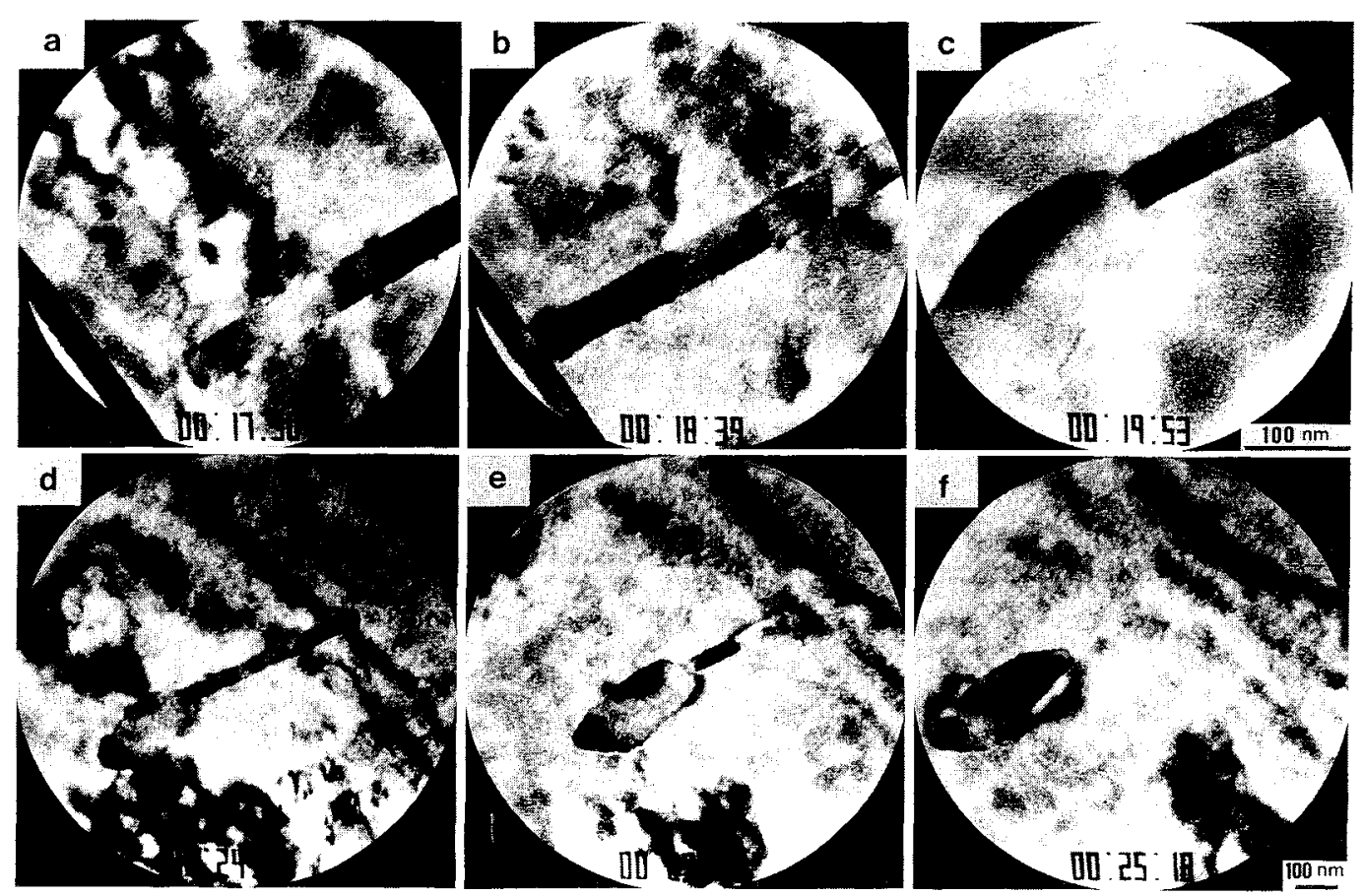

Fig. 2 Successive stages of the $\theta^{\prime} \rightarrow \theta$ phase transformation. A foil specimen was made by $i n$-situ annealing at $643 \mathrm{~K}$. The micrographs $(\mathrm{d}) \sim(\mathrm{f})$ were taken by a low magnification.
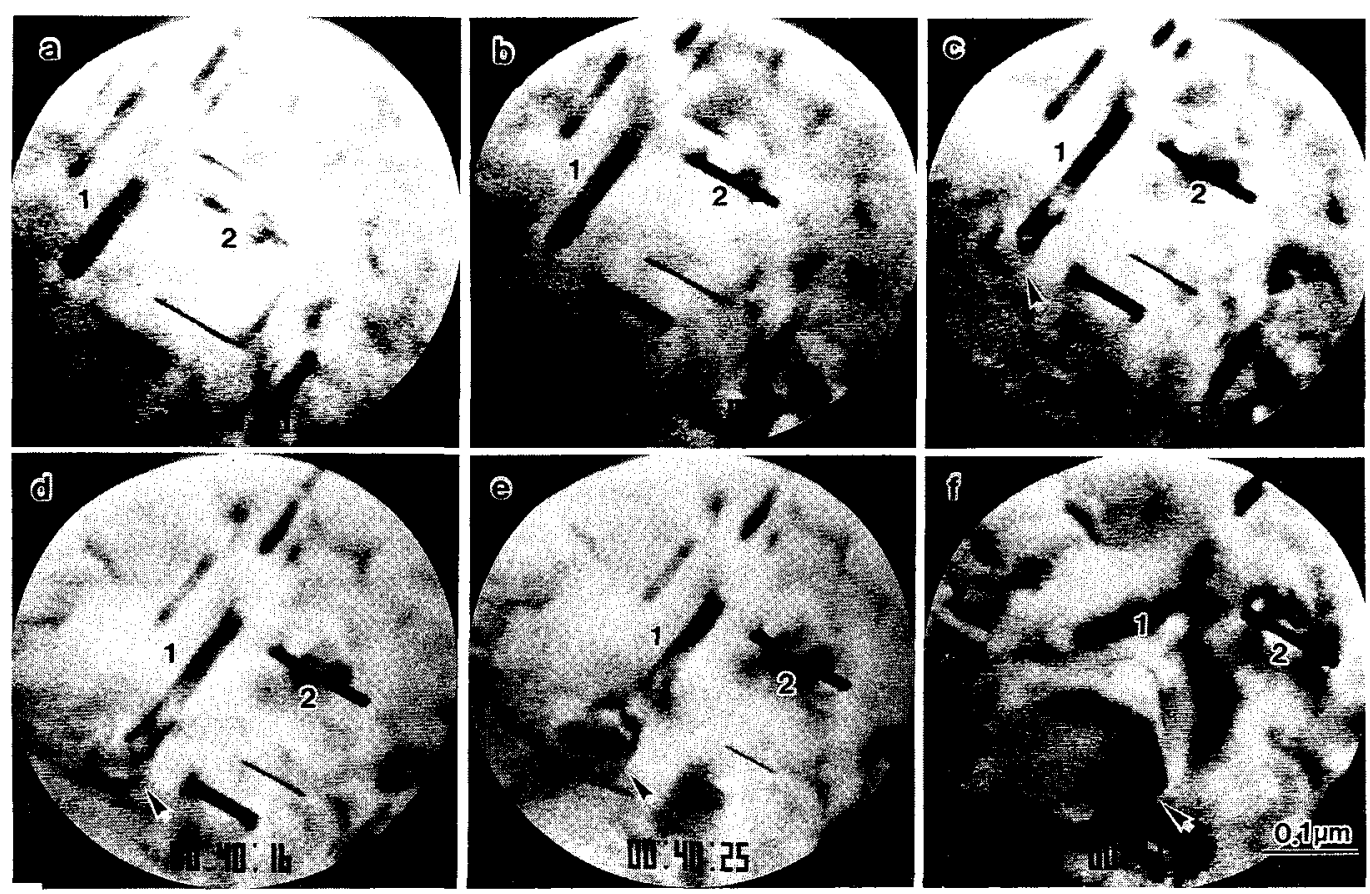

Fig. $3 \quad \theta^{\prime} \rightarrow \theta$ phase transformation process. A foil specimen was made by $i n$-situ annealing at $673 \mathrm{~K}$. Micrographs (a) and (b) show the growth process of the $\theta^{\prime}$ - phase indicated by mark 1 , and (c) shows the nucleation of the $\theta$-phase indicated by an arrow at the end of $\theta^{\prime}$-phase indicated by mark 1 , and (d)-(f) show the growth process of the $\theta$-phase indicated by an arrow. 


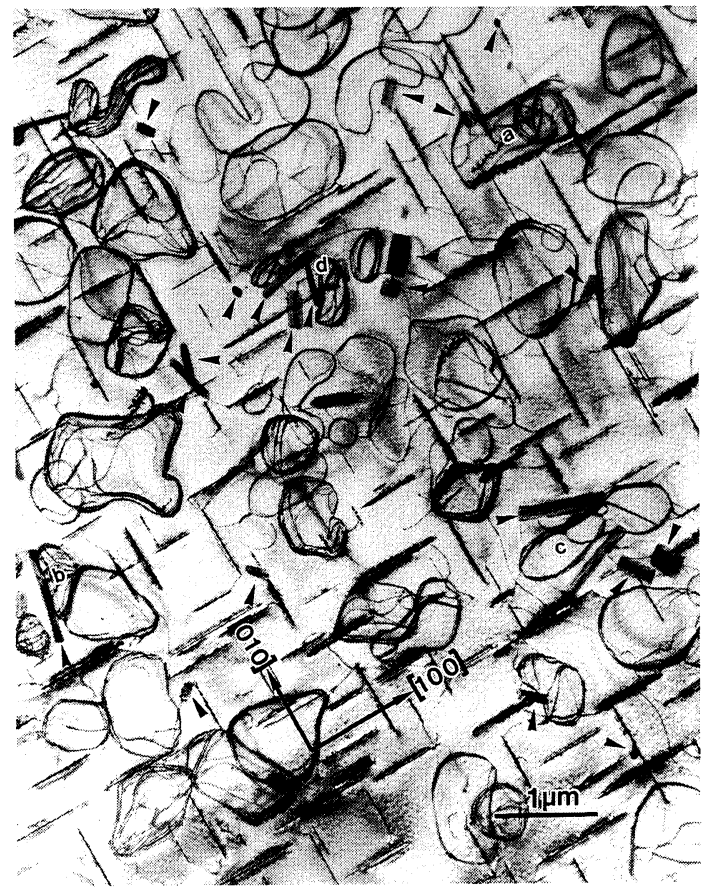

Fig. 4 Relation between the $\theta^{\prime}$ - and $\theta$-phases formed in a bulk specimen aged at $623 \mathrm{~K}$ for $0.3 \mathrm{ks}$. The $\theta$ phase crystals are indicated by arrows.

状またはアスペクト比の大きい板状析出物である.したが って，矢印で示したように，前述の $\theta^{\prime}$ 相とは容易に判別 できる.この Fig. 4 では, $\theta$ 相の数は $\theta^{\prime}$ 相のそれの約 15〜20\%ほどに到達している.ところで，Fig. 4 では試 料表面に平行な $\theta^{\prime}$ 相の形状は円盤状のものもあるが, 歪

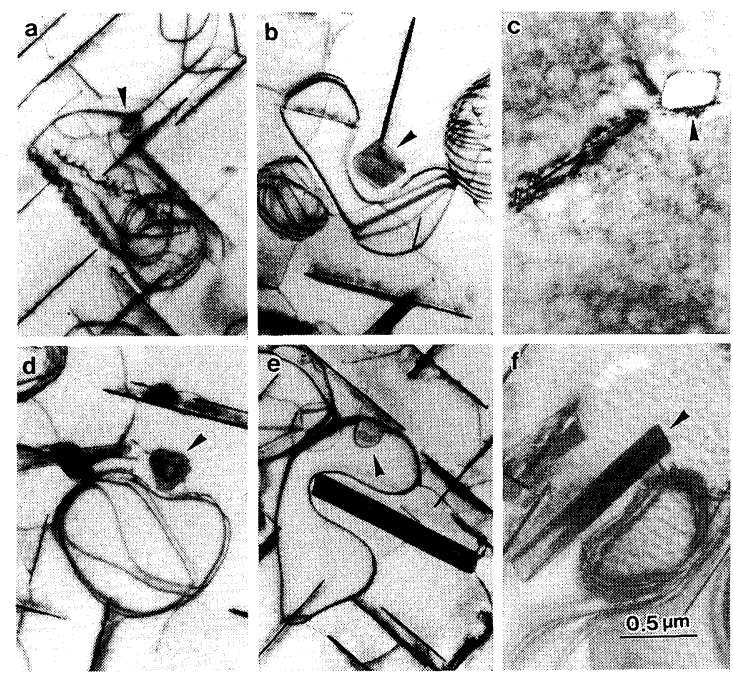

Fig. 5 Structures of the $\theta^{\prime}$ - and $\theta$-phases formed in a bulk specimen aged at $623 \mathrm{~K}$ for $0.3 \mathrm{ks}$. The $\theta$-phase crystals are indicated by arrows.
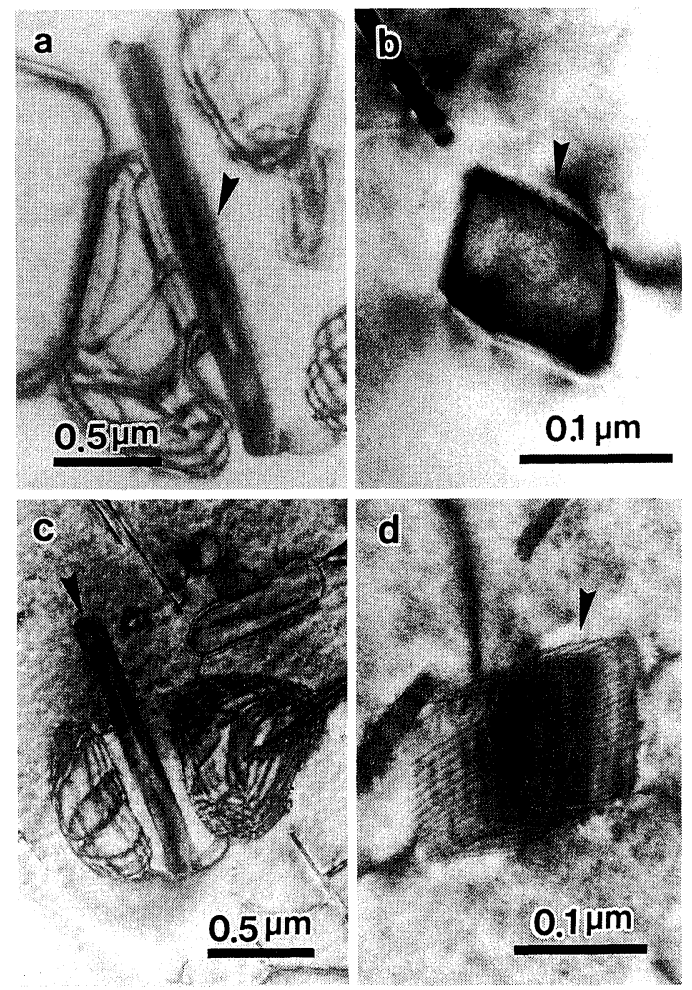

Fig. 6 Structures of the $\theta^{\prime}$ - and $\theta$-phases in a bulk specimen aged at $623 \mathrm{~K}$ for $0.3 \mathrm{ks}$. The $\theta$-phase crystals are indicated by arrows.

んだ形状のものが多い，そこで，母相の 3 つの $\{100\}_{\alpha}$ 面 に平行に切り出した試料を用いて， $\theta^{\prime}$ 相と $\theta$ 相の相関を調 ベたものを Fig. 5 扎よび $\mathbf{6}$ に示す.これらの写真から， それぞれ次のことが分かる。 (1) Fig. 5(a)〜 (d)で見られる ように, $\theta$ 相 $(\uparrow)$ は, Fig. 2 および 3 の薄膜試料時効の場 合之同様に，その形成は必ず何れかの $\theta^{\prime}$ 相の一部で起こ る. (2)この際， $\theta$ 相は 2 枚の $\theta^{\prime} か ゙$ 相遇(Fig. 5(a))，または 互いに極く近傍に存在する場所で形成される頻度が高い.

(3)形成された $\theta$ 相の断面は，その初期には円形(Fig. 5(a) および $(\mathrm{e}))$ または後述の平行四辺形を半分に切ったような 3 角形状 (Fig. 5(d)) であるが，一般には平行四辺形状 (Fig. 5(b) および (c)) であり, 長手方向の形状を示す Fig. 5(e) 扎よび(f)から分かるように, 全体としては棒状 またはアスペクト比の大きい平板状である. (4) $\theta$ 相は形成 と同時に母相を激しく歪ませ，バルク状態で形成されたも のを電顕用薄膜に仕上げる際には，膜厚が或る程度薄くな ると Fig. 5(c)のようにしばしば試料から抜け落ちる. (5) 長手に成長した $\theta$ 相では Fig. $5(\mathrm{~b}) ，(\mathrm{~d}) \sim(\mathrm{f})$ で見られるよ らに，その近傍にある $\theta^{\prime}$ 相とは一見反発するように互い に離れて成長する. (6) Fig. 6 で(a)と (b)は(1)の項に対応 すると思われる $\theta$ と $\theta^{\prime}$ 相との関係を，また(c)と(d)は(5) の項に対応すると思われるもので，(a) および(c)は $\theta$ 相が 
試料面にほぼ平行に，(b) および(d)は $\theta$ 相が試料面に垂 直に近い状態にある場合の両者の関係を示している. (7)形 成された $\theta$ 相と近傍の $\theta^{\prime}$ 相は殆ど例外なく転位線で結ば れている(Fig. 5(b)，(d)〜 (f) および Fig. 6(c)). これら 転位線は $\theta$ 相の成長時の $\mathrm{Cu}$ 原子拡散と関係している可能 性が強い.

\section{3. $\theta$ 相の原子構造と界面組織}

$\theta^{\prime}$ 相と $\theta$ 相は化学組成は同一であるにもかかわらず，そ の原子構造は大きく異なり，母相に及ぼす格子歪もまた大 きい，そこで，時効処理を行った試料について $\theta$ 相と母相 との関係を高分解能電顕像で調べたのが Fig. 7 である. この写真から次のことが分かる. (1) $\theta$ 相の $\{110\}_{\theta}$ 面の 1 つは母相の $\{100\}_{\alpha}$ 面の 1 つと平行である. (2)両相の界面 ではこの互に平行な結晶面とさらに $\theta$ 相の $\{100\}_{\theta}$ 面の 1 つ(个)とによって階段状構造 (ledge)を形成する. (3)この 界面では， $\theta$ 相の $\{110\}_{\theta}$ 界面に平行に $\theta^{\prime}$ 相と類似した構造 の緩和層 (buffer layer)が単一矢印で示した如く形成され る、ただし，その層の厚みは段階状構造のステップと同程 度に止まる。(4)界面に拈ける階段状構造のテラスの長さ （したがって，界面全体の方位）は場所によって異なり，薄 膜で時効処理を行った場合には界面に生ずる階段状構造も 不明瞭となると同時に，大幅にその全体としての方位を変
化させる. Fig. 8 は薄膜試料を時効処理した時の一例で, Aのように界面全体としての方位のすべてが $\{100\}_{\alpha}$ の 1 つと一致するものから，Bの矢印で示した部分のように $\{100\}_{\alpha}$ に30度も傾いているものまで現れる.

上述のように，バルク試料を加熱して形成された $\theta$ 相の 界面には階段状構造が現れるが，この構造はFig. 6(b) お よび(d)の ledge 部分に生じた界面転位と考えられる像か ら分かるように $\theta$ 相の析出初期から界面全体に形成され る.なお，Fig. 6(d) で写真の上下方向に現れている縞模 様は， $\theta$ 相界面に現れた等厚干渉縞で，この $\theta$ 相が試料を 上下方向に貫通した柱状であることが分かる。また， Fig. 7 から分かるように, $\theta$ 相内部には何らの組成も現れ ない.

\section{N. 考察および結論}

本実験で得られた結果を要約すると次の如くになる（a) $\theta^{\prime}$ 相の成長先端には界面転位が存在し，母相の歪は大き い。(b)既に報告した如く(11)， $\theta^{\prime}$ 相は双晶のようにその $\{100\}_{\theta^{\prime}}$ の 1 つを主成分とする階段状構造を形成し，それ らが同一面に沿って移動することによって成長する. (c) $\theta$ 相は $\theta^{\prime}$ 相が交差した場所で形成され易い。その場合の核 形成は $\theta^{\prime}$ 相内で起きる。(d) $\theta$ 相は棒状またはアスペクト

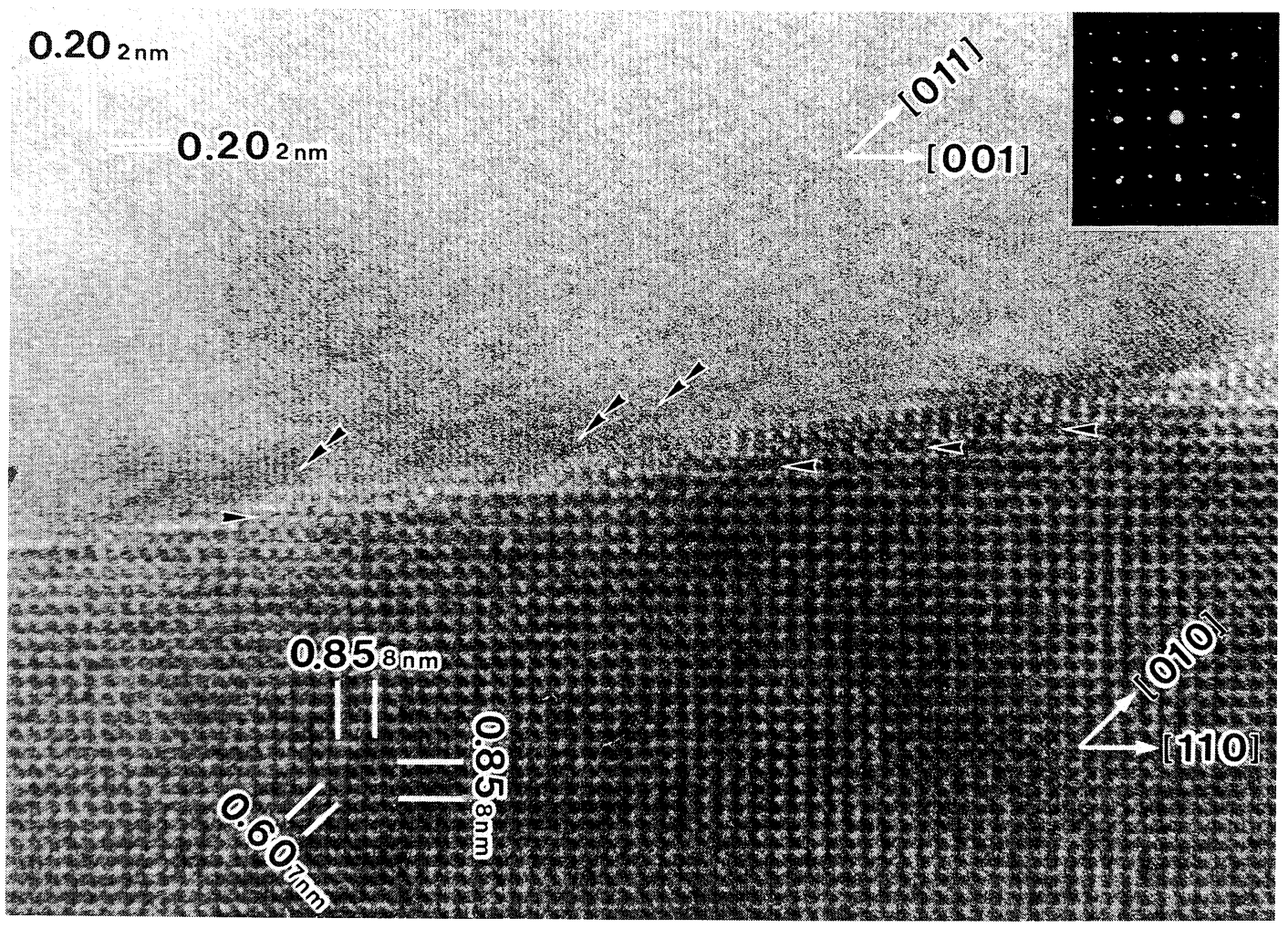

Fig. 7 Lattice images and an electron diffraction pattern of the interface between $\mathrm{Al}$ matrix and $\theta$-phase. The (i00) planes and buffer layers formed on (110) of $\theta$-phase are indicated by double and single arrows respectively. 


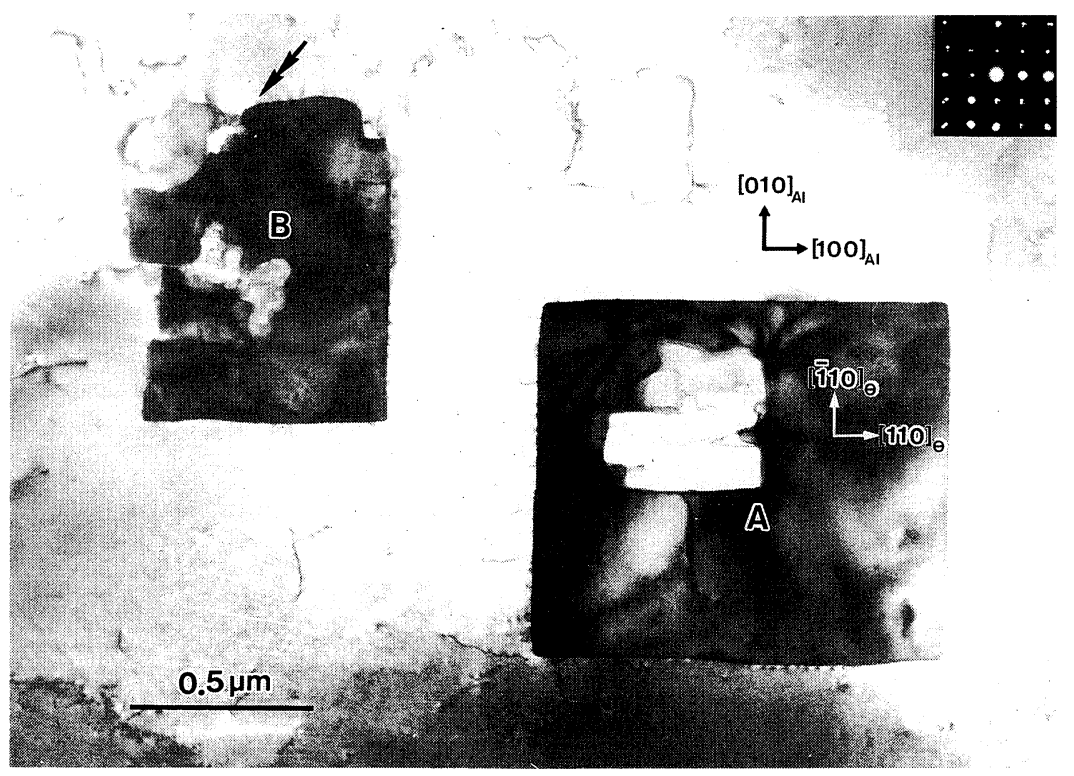

Fig. 8 The $\theta$-phase formed in a foil specimen by in-situ aging at $643 \mathrm{~K}$.

比の大きい板状に成長するが，成長は隣接する $\theta^{\prime}$ 相を吸 収する形で行われる。ただし，成長するにつれてそれら $\theta^{\prime}$ 相の界面と $\theta$ 相の界面は僅かながら離れた形をとる。(e) $\theta$ 相は母相と一組の $\{100\}$ 面を共有するが，そのバルク材 時効時の界面は，この合金では一般に母相の $\{100\}_{\alpha}$ 面の 1 つに約13度の傾きを持つ。また，この $\theta$ 相の界面は $\theta$ 相 の $\{110\}_{\theta}$ の 1 個と $\{100\}_{\theta}$ の 1 つより構成され, 全体の傾 きはバルク試料では上述のよ5に約 13 度と一定している が，薄膜を時効した場合には広範な角度をとる. 以上の結 果の中, 項目 (a) と(b)より， $\theta^{\prime}$ 相はその不整合界面の比率を 増大させないため, 長手方向には成長し易いが，安定な界 面からなる厚さ方向には成長し難いこと．また，項目(e)よ り，整合歪の大きい界面は階段状構造をとること，および それら階段状構造の移動が $\theta$ 相の成長に関係していること が分かる。

これらの結果から $\theta^{\prime} \rightarrow \theta$ 相変態の機構を以下に考察す る.

\section{1. $\theta$ 相と $\mathrm{Al}$ 母相との方位関係}

$\theta^{\prime} \rightarrow \theta$ 相変態の機構について考える前に，まず $\theta$ 相と $\mathrm{Al}$ 母相との関係を考えてみる. Fig. 9 はこれら $\theta^{\prime}(\mathrm{b}) ， \theta$ (c)および $\mathrm{Al}$ 母相 (a)の結晶構造を示したものであるが, 3 者に共通なことは, (1)いずれの結晶構造にも $\mathrm{Al}$ 原子の みで構成された結晶面があり，(2)その面はつねに $\mathrm{Al}$ 母相 の 1 組の $\{100\}_{\alpha}$ 面と平行で, (3)その面上の $\mathrm{Al}$ 原子の配列 も非常に類似していることである.もちろん，これら $\mathrm{Al}$ 原子間距離は近くに存在する $\mathrm{Cu}$ 原子の位置と配位数によ って影響はうけるが， $\theta^{\prime} \rightarrow \theta$ 相変態にはこのような $\mathrm{Al}$ 母 相の 1 組の $\{100\}_{\alpha}$ 面が基本となると考兄られる．ところ
で，Fig. 9(a)および(b) で見られる如く， $\mathrm{Al}$ 母相と $\theta^{\prime}$ 相 に関しては $\mathrm{Cu}$ 原子の存在による影響を緩和層(9)で緩和す ること以外は, 両者間の適合性は極めて良好なことが理解 できる。しかし，c 軸方向の格子常数が大きく異なること から， $\theta^{\prime}$ 相の成長は $(001)_{\theta}$ 面に沿ら階段状構造の ledge $の$ 移動によって行われることが容易に理解できる.

これに対して，Al 母相と $\theta$ 相では条件が大きく異なり， Fig. 10 に示したようになる.この図の左半分は純 $\mathrm{Al}$ 母 相と $\theta$ の間の界面の原子構造を画いたものであるが，図か ら分かるように, $\{110\}_{\theta}$ と $\{100\}_{\alpha}$ の格子常数の差は, $(0.429-0.404) \mathrm{nm}=0.025 \mathrm{~nm}$ であるのに対して, $\{100\}_{\theta}$ と $\{110\}_{\alpha}$ のそれは $(0.607-0.517) \mathrm{nm}=0.03 \mathrm{~nm}$ であり， 後者の方が大きいために，その長さは相対的に短くなる. しかも，前者はFig. 10 の右半分に示したよらに， $\mathrm{Al}$ 母 相の $\mathrm{Cu}$ 原子濃度が増加するほど減少するため, この面の 長さはさらに長くなり得る，その結果，析出に伴ら格子歪 が容易に緩和できる薄膜試料の時効では，界面における $\mathrm{Cu}$ 原子濃度は大幅に変化できるために, $\theta$ 相の全体とし て界面はFig. 8 に示した如く大幅変化するものと考えら れる。

\section{2. $\theta^{\prime} \rightarrow \theta$ 相変態機構}

この両相では, 化学組成は $\mathrm{Al}: \mathrm{Cu}=2: 1$ と不変であり, しかも $\mathrm{Al}$ 母相に対して共に一組の $\{100\}_{\alpha}$ を共有する共通 の性質を持っている。 また，共に界面ではその近傍に $\{100\}_{\alpha}$ に平行な緩和層を形成することも類似している. 更に $\theta$ 相は laves 相であり，Al原子層と $\mathrm{Cu}$ 原子層は Fig. 9 に見られるように互に回転して，Al-Al 原子間距離 は縮小する反面， $\mathrm{Al}-\mathrm{Cu}$ 原子間距離は増大寸る. そのため, 


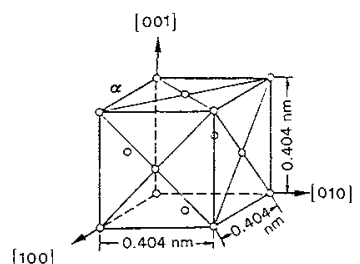

(a)

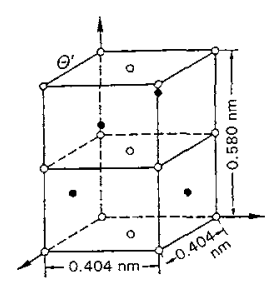

〈b〉

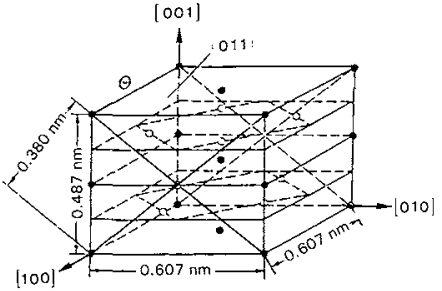

(C)

Fig. 9 Crystal structures of Al matrix (a), $\theta^{\prime}$-phase (b) and $\theta$-phase (c).

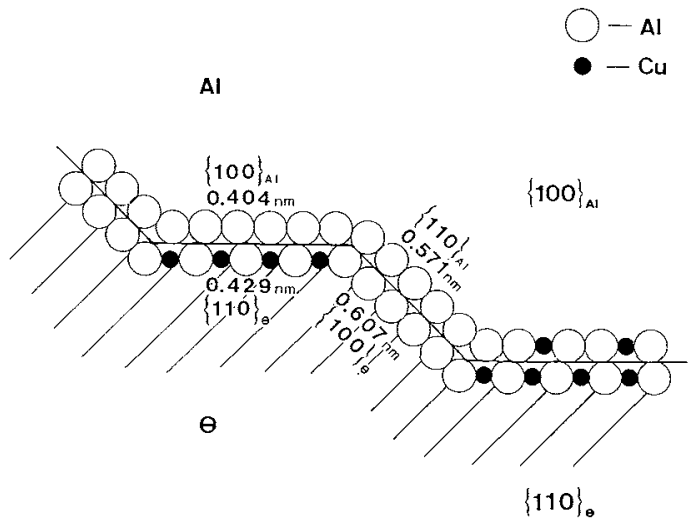

Fig. 10 Schematic illustration of atomistic structure of $\theta$-phase interface.

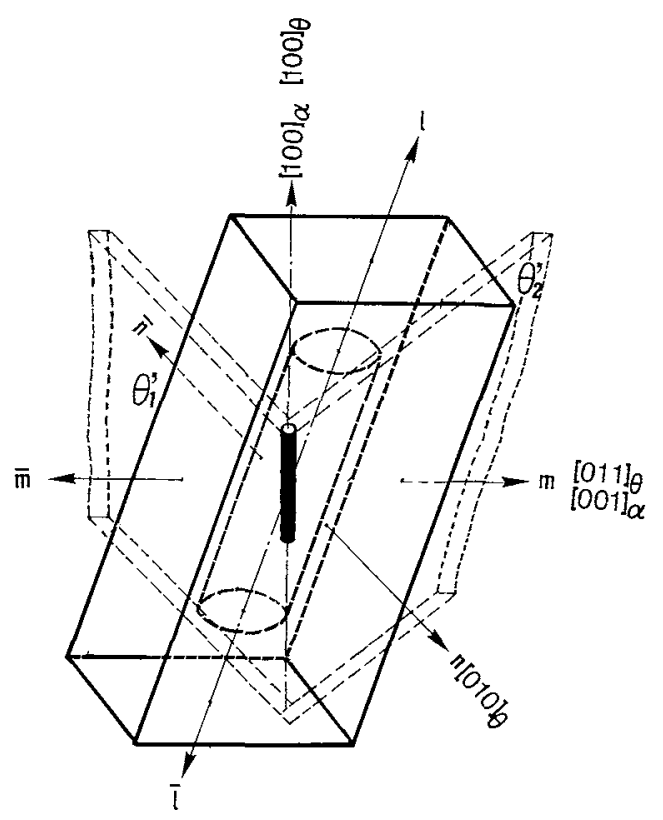

Fig. 11 Schematic illustration of growth process of $\theta$-phase.

$\theta^{\prime} \rightarrow \theta$ 相変態は $\mathrm{Cu}$ 濃度が同一な $\theta^{\prime}$ 相の一部で起こり易い. この際，2枚の相異なる系の $\theta^{\prime}$ 相の相遇したところが Cu
原子数も多く，格子昰も大きいため， $\mathrm{Al}$ および $\mathrm{Cu}$ 原子 が動き易くなり，日相の核形成場所となる可能性が非常に 大きくなると考完られる．Fig. 11扎よびFig. 12 はこの 過程を図示したるのである。まず形成される $\theta$ 相は $\mathrm{Al}$ 母 相に対して体積変化が大きいため棒状となり，成長初期で は2枚の $\theta^{\prime}$ 相の相遇場所近傍が有利となる。たたしこ の際には, $\mathrm{A} 1$ 地の $\{100\}_{\alpha}$ 面の 1 つと平行な $\{110\}_{\theta}$ 面の 1 つは，Fig. 10 のらに整合歪が比較的小さいため，その 面を中心として界面はFig. 7 のよ5な階段状構造を形成 すると考觉られる。

Fig. 11 おょびFig. 12 で中央の棒状のものがその $\theta$ 相 の形成初期を表わし，つついて成長につれて界面に段階状 搆造が形成されると共に $\theta$ 相は円柱状となる。この際, 図 の 1 方向 $\left([100]_{\theta}\right)$ では整合歪の少ないことから成長は早 く，円柱状はこの力向に伸びる。この際， $n\left([010]_{\theta}\right)$ 敊よ び $m\left([011]_{\theta}\right)$ 方向では $\theta$ 相と $\mathrm{Al}$ 母相との結晶構造の関係 を示した Fig. 12 から分かるよらに $(011)_{\theta}$ 面の方が $(010)_{\theta}$ 面より $\mathrm{Al}$ 母相に対して整合度が暿いため，階段構造はよ り発達し，各テラスの長さも短くなる。したがって，これ ら ledge の移動による $\theta$ 相の成長は Fig. $11 の m$ 面の方 が $n$ 面より容易となり， $\theta$ 相の断面は Fig. 12 のらに平 行四辺形状になると考えられる。

一方，[100] $]_{\theta}$ 方向に伸び，\{011 $\}_{\theta}$ 面に形成される ledgeは，(010) $\theta$ の界面エネルギーを下げるため，Fig. 13 に示したよらに局所的に集合して長手の $[100]_{\theta}$ の方向 に沿って大きいledgeを形成すると考えられる。このこと が $\theta$ 相の成長軸 $[100]_{\theta}$ が $\mathrm{Al}$ 母相の $[001]_{\alpha}$ よりずれる理 由で，勿論 $\mathrm{Cu}$ 原子濃度にも影響されるが，本合金では 5〜7 個の ledge が集合して約 $20 \mathrm{~nm}$ 程度の大きい間隔で ゆるやかに傾いた ledgeを形成したと考えられる。

\section{3. $\theta$ 相界面エネルギーの評価}

今，温度を一定に保った時の $\theta$ 相の核形成を考えると， その $\theta^{\prime}$ 相に対する $\theta$ 相の緄自由エネルギー差 $\Delta E_{\mathrm{T}}\left(\theta / \theta^{\prime}\right)$ は次のよらに表わされる(12).

$$
\begin{aligned}
\Delta E_{\mathrm{T}}\left(\theta / \theta^{\prime}\right)= & \Delta E_{\mathrm{V}}\left(\theta / \theta^{\prime}\right)+E_{\mathrm{S}}\left(\theta / \theta^{\prime}\right) \\
& +E_{\mathrm{L}}\left(\theta / \theta^{\prime}\right)+\alpha \Delta V\left(\theta / \theta^{\prime}\right)^{m}
\end{aligned}
$$

ここで, $\Delta E_{\mathrm{V}}\left(\theta / \theta^{\prime}\right)$ は両者間の体積自由エネルギー差, $E_{\mathrm{S}}$ $\left(\theta / \theta^{\prime}\right)$ はと $\theta \theta^{\prime}$ 相の界面エネルギー, $E_{\mathrm{L}}\left(\theta / \theta^{\prime}\right)$ は両相に 


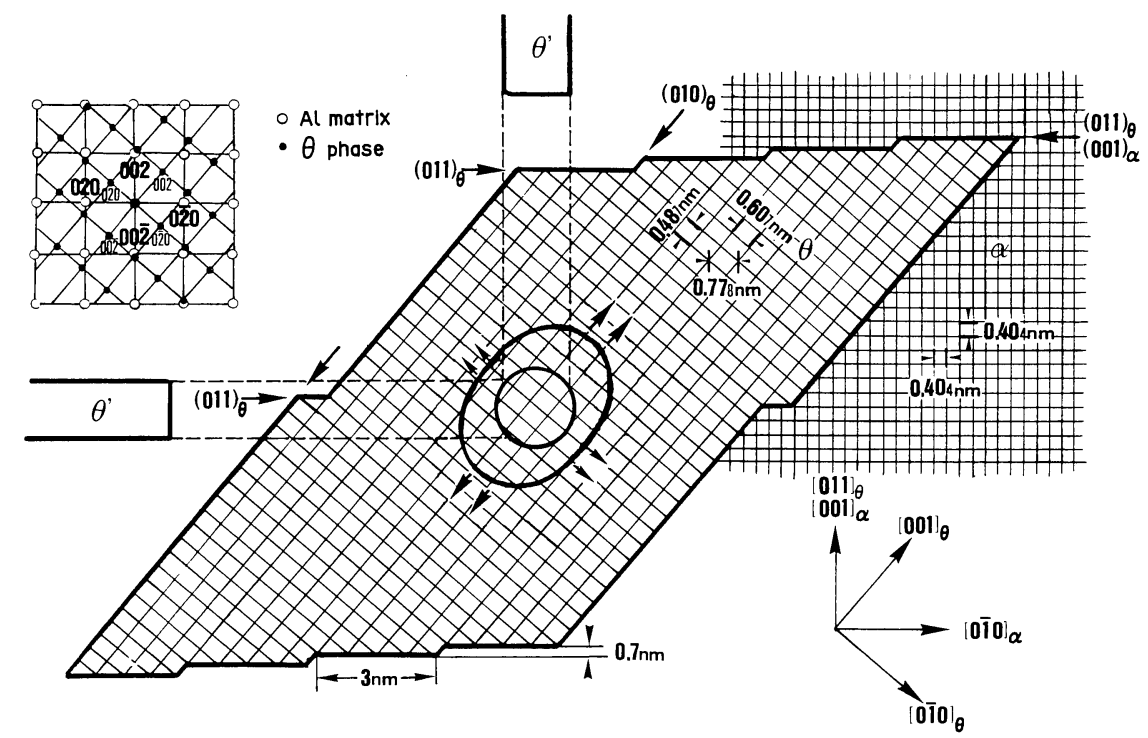

Fig. 12 Orientation relationships between the matrix $(\alpha)$, the $\theta^{\prime}$ - and $\theta$-phases.

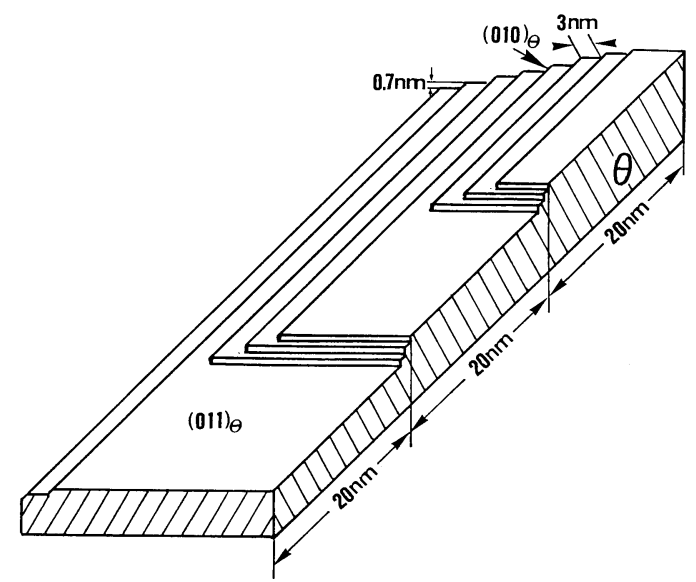

Fig. 13 Schematioc illustration of stepped structures of $\theta$-phase interfaces.

おける配位数の差による格子歪項, $\alpha \Delta V\left(\theta / \theta^{\prime}\right)^{m}$ は両相の 全体積差 $\Delta V$ に依存する昰エネルギ一項である。いま， 2 組の $\theta^{\prime}$ 相の相遇点で $\theta$ 相の核形成が起きる場合には, ま ず $\mathrm{Cu}$ 原子の長距離拡散を必要としないため, $E_{\mathrm{L}}\left(\theta / \theta^{\prime}\right)$ は 比較的小さくなり, 核形成初期では $\alpha \Delta V\left(\theta / \theta^{\prime}\right)^{m}$ もをた 小さい. したがって, 右辺第 1 項の絶対値が, $\mathrm{Al}$ 母相 $(\alpha$ 相)に対するもの, $\left|\Delta E_{\mathrm{V}}(\theta / \alpha)\right|$, よりも小さくても, $E_{\mathrm{S}}$ としては Fig. 9(c)で $(001)_{\theta}$ と $(001)_{\theta^{\prime}}$ との整合を考えれば よいので $\Delta E_{\mathrm{T}}$ は十分負として大きい值をとり得る．とこ ろが， $\theta$ 相が大きくなるにつれて $E_{\mathrm{L}}$ 項は急速に消隇する と同時に, 右辺第 4 項は急速に大きくなる. しかも, $\theta$ 相 は棒状となるために, $E_{\mathrm{S}}$ としては, 整合性の悪いFig. $9(\mathrm{c})$ の $(010)_{\theta}$ と $\{100\}_{\theta}$ も考えねばならず，大きい值とな り，結果として， $\Delta E_{\mathrm{T}}$ は負の值をとり難くなる．同様の ことを $\theta$ 相と $\alpha$ 相との間で考えて見ると， $\alpha \Delta V^{m}$ の項は $\theta^{\prime}$ 相に対するより小さくなり, また $\theta$ 相は安定相であるこ

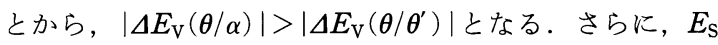
としては，(001) ${ }_{\alpha}$ と $(011)_{\theta}$ が主役となるので, $E_{\mathrm{S}}(\theta / \alpha)$ $<\left|\Delta E_{\mathrm{V}}(\theta / \alpha)\right|$ となり得る. 以上の $\theta$ 相対 $\theta^{\prime}$ 相と $\theta$ 相対 $\alpha$ 相の関係を比較すると, 成長した $\theta$ 相の界面はFig. 5 お よび 6 で見られるよらに， $\theta^{\prime}$ 相のそれと離れた方が有利に なると考えられる.な拈, 成長した $\theta$ 相の階段状界面の詳 細については別途報告する.

\section{文献}

(1) V. Gerold: Scripta Met., 22(1988), 927.

(2) V. A. Phillips: Acta Met., 23(1975), 751.

(3) G. Tomas and M. J. Whelan: Phil. Mag., 6 (1960),1103.

(4) M. Wada, H. Kita and T. Mori: Acta Met., 33 (1985), 1631.

( 5 ) K. Hono, T. Satoh and K. Hirano: Phil. Mag., 53 (1986), 495.

( 6 ) K. Hono, T. Hashizume, Y. Hasegawa, K. Hirano and T. Sakurai: Scripta Met., 20 (1986), 487.

( 7 ) H. Fujita, H. Nakayama and Y. Fuchida: Phil. Mag. A., 59(1989), 4, 873.

（8）根本 実, 幸田成康：日本金属学会誌, 27 (1963), 599.

(9) H. Fujita, E. Taguchi and Chen Lu: J. Elect. Micros., 37, No. 6 (1988), 323.

(10) J. M. Silcock, T. J. Heal and H. K. Hardy: J. Inst. Metals, 82 (1953-54), 239.

（11）呂忱, 田口英次, 藤田広志 : 日本金属学会春期 講演概要, (1988·4 月), 94 .

(12) H. Fujita: J. Electron Microscopic Tech., 3(1986), 45. 